\title{
The Effect of Weed Control on the Growth and Yield of Shallot (Allium ascalonicum L.)
}

\author{
Husni Thamrin Sebayang*, Pebrio Adi Prasetyo
}

\author{
Department of Agronomy, Brawijaya University, INDONESIA \\ *coreesponding: husni_thsby@yahoo.co.id
}

\begin{abstract}
Weeds are one of several factors that cause decreased shallot production. Weed control is needed to increase production. The experiments to study the effect of weed control on the growth and yield of shallot had been conducted from June 2019 to September 2019 at Kepuharjo Village in Karangploso Sub-District, Malang Regency. The experiment used a randomized block design (RBD) with 6 treatments and 4 replications. The results showed that for treatment of weed-free, weeding at 15, 30 and 45 DAP (Days after planting), application of oxyfluorfen herbicides at a dose of $1.5 \mathrm{l} / \mathrm{ha}+$ weeding at $30 \mathrm{DAP}$, silver black plastic mulch + weeding at 30 DAP and straw mulch rice + weeding at 30 DAP the dry weight of weed significantly decreased. The growth and yield of shallot showed significantly higher with weed free treatment followed by weeding 15, 30 and 45 DAP, application of oxyfluorfen herbicide at a dose of $1.5 \mathrm{l}$ ha + weeding at $30 \mathrm{DAP}$, silver black plastic mulch + weeding at 30 DAP and rice straw mulch + weeding at 30 DAP treatments. The growth and yield of shallot showed significantly lower with the treatment of without weed control compared with the other weed control treatments.
\end{abstract}

Keywords — Shallot, Weed and Weed Control.

\section{INTRODUCTION}

The shallot plant is one of the essential plants in society that functions as a spice for food and traditional medicine, and has been cultivated by farmers for a long time. The need for shallots continues to increase in line with the growing population of Indonesia, which leads to shallots having a quite high economic value. In Indonesia, the consumption of shallots tends to increase with an average growth of $8.31 \% \mathrm{~kg} /$ capita/ year and shallot production has increased by $3.93 \% /$ year. The increase in production was caused by an increase in harvesting area by $7.16 \% /$ year and productivity by $1.05 \%$ / year (Center for Data and Agriculture and Information System, Ministry of Agriculture, 2016).

Various appropriate cultivation technologies continue to be applied to increase the production of shallot plants. One of the factors that interfere the production of onion family and increase cultivation cost is the presence of weeds around plants (Vijayvergiya, 2018). Onion plants are considered as weak competitors against weeds because of their slow growth, short plant shape, shallow roots system, upright leaves and cylindrical shape making them less able to suppress the growth of weeds through the closure of plant shade (Sekara, et al., 2017). The presence of weeds can reduce crop yields because of competition for growth factors such as water, light, air, nutrients and weed also become host for pests or diseases (Bhullar, et al., 2015). Weed competition with weed can reduce onion bulbs yield by $30-60 \%$ (Tripathi, et al., 2013). Control of weeds on shallots needs to be performed to increase crop yields.

\section{MATERIAL AND METHOD}

An experiments to study the effect of weed control on the growth and yield of shallot had been conducted from June 2019 to September 2019 at Kepuharjo Village in Karangploso Sub-District, Malang Regency, at an altitude of $\pm 525 \mathrm{~m}$ above sea level and with an averages rainfall of approximately $1000 \mathrm{~mm}$, average daily temperature of 14 ${ }^{0} \mathrm{C}$ and clay-type soil. The experiment used a randomized block design (RBD) consisting of 6 treatments that were repeated 4 times. The treatment of weed control are $\mathrm{P} 0$ : without weed control, P1: weed free, P2: weeding at 15, 30 and 45 DAP (Days after planting), P3: application of oxyfluorfen herbicide with a dose of 1.51 /ha + weeding at 30 DAP, P4: silver black plastic mulch + weeding at 30DAP and P5: rice straw mulch + weeding 30 DAP. Tillage was performed by dredging the soil with a hoe 2-3 times until the soil becomes loose. Seedbed for experimental plot were then made with placement of 2.5 $\mathrm{m} \times 1.5 \mathrm{~m}$, seedbed heights of $30-40 \mathrm{~cm}$, the seedbed placed $50 \mathrm{~cm}$ apart, and the replications placed $50 \mathrm{~cm}$ apart. Seedlings of Tajuk shallot variety were planted with spacing of $15 \times 15 \mathrm{~cm}$. The basic fertilizer consists of 
$250 \mathrm{~kg} / \mathrm{ha}$ of SP 36 and $200 \mathrm{~kg} / \mathrm{ha}$ of NPK given after planting. At the age of 15 DAP, $200 \mathrm{~kg} / \mathrm{ha}$ of NPK fertilizers was given and at the age of $30 \mathrm{DAP}, 200 \mathrm{~kg} / \mathrm{ha}$ of NPK fertilizers and $150 \mathrm{~kg} / \mathrm{ha}$ of ZA fertilizer was given. Fertilizing was performed around the rows of shallot plants. Watering was performed every 2-3 days in accordance with plant conditions. Weed control in weedfree treatment was performed every 3-5 days if there are weeds that grew. Weed control with oxyfluorfen herbicide was performed using a hand sprayer at a dose $1.5 \mathrm{l} / \mathrm{ha}$ with a water volume of 500 1/ha. Silver black plastic mulch and rice straw mulch was applied before planting. Silver black plastic mulch was perforated to grow plants. Rice straw mulch was spread with a thickness of approximately 2-3 cm, and the shallots were then planted between rice straw mulch. Weeding according to treatment was performed manually using a sickle or hoe. Observation of weed dry weight, weed control efficiency (WCE) and weed index (WI) as well as the growth and yield of shallots were carried out at 15,30, 45 and 60 days after planting. The obtained data were analyzed using analysis of variance ( $\mathrm{F}$ test) with a level of $5 \%$ to determine the effect of the treatment. If significant occur, the LSD (Least Significant Difference) test was carried out with a level of $5 \%$.

Weed Control Efficiency (\%)
Weed control was calculated by using the following formula (Prachand,et al., 2014):

$$
\operatorname{WCE}(\%)=\frac{\text { DWC-DWT }}{\text { DWC }} \times 100(1)
$$

Where, WCE $=$ Weed control efficiency $(\%)$, DWC $=$ Dry weight of weed in control plot, DWT $=$ Dry weight of weed in treatment plot.

Weed Index (\%)

Weed index was calculated by using the following formula (Prachand,et al., 2014):

$$
\text { Weed index (WI) } \%=\frac{X-Y}{X} \times 100(2)
$$

Where, $X=$ Weight of bulbs yields in treatment which highest yield, $\mathrm{Y}=$ Weight of bulbs yields from the treatment plot.

\subsection{Weed Growth}

\section{RESULT AND DISCUSSION}

Weed control significantly affected the weed dry weight observed at 15, 30, and 60 DAT (Table 1). The weed dry weight was significantly higher in P0 treatment (without weed control) at observations of $15,30,45$ and 60 DAP being $0.70,26.98,38.63$ and $63.80 \mathrm{~g} / 0.3 \mathrm{x} 0.4 \mathrm{~m}$ respectively, and significantly lower in the $\mathrm{P} 1$ (weed-free) treatment being $0.25,0.38,0.43$ and $1.23 \mathrm{~g} / 0.3 \times 0.4 \mathrm{~m}$ respectively compared to other weed control treatments.

\begin{tabular}{|c|c|c|c|c|c|c|c|c|}
\hline \multirow{2}{*}{ Treatments } & \multicolumn{4}{|c|}{$\begin{array}{l}\text { Observed weed dry weight }(\mathrm{g} / 0.3 \times 0.4 \mathrm{~m}) \text { at } \\
\text { various DAP }\end{array}$} & \multicolumn{4}{|c|}{ Observed WCE (\%) at various DAP } \\
\hline & 15 & 30 & 45 & 60 & 15 & 30 & 45 & 60 \\
\hline P0 & $\begin{array}{l}1.09 \mathrm{c} \\
(0.70)\end{array}$ & $\begin{array}{l}5.21 \mathrm{~d} \\
(26.98)\end{array}$ & $\begin{array}{l}6.21 \mathrm{~d} \\
(38.63)\end{array}$ & $\begin{array}{l}7.96 \mathrm{~d} \\
(63.80)\end{array}$ & & & & \\
\hline P1 & $\begin{array}{l}0.87 \mathrm{a} \\
(0.25)\end{array}$ & $\begin{array}{l}0.93 \mathrm{a} \\
(0.38)\end{array}$ & $\begin{array}{l}0.95 \mathrm{a} \\
(0.43)\end{array}$ & $\begin{array}{l}1.31 \mathrm{a} \\
(1.23)\end{array}$ & 61.25 & 98.55 & 98.92 & 97.88 \\
\hline $\mathbf{P 2}$ & $\begin{array}{l}0.95 \mathrm{ab} \\
(0.40)\end{array}$ & $\begin{array}{l}2.81 \mathrm{~b} \\
(7.43)\end{array}$ & $\begin{array}{l}2.04 \mathrm{bc} \\
(3.98)\end{array}$ & $\begin{array}{l}3.46 \mathrm{bc} \\
(11.65)\end{array}$ & 35.63 & 71.06 & 88.61 & 80.31 \\
\hline P3 & $\begin{array}{l}0.87 \mathrm{a} \\
(0.25)\end{array}$ & $\begin{array}{l}2.39 \mathrm{~b} \\
(5.30)\end{array}$ & $\begin{array}{l}1.83 \mathrm{bc} \\
(3.23)\end{array}$ & $\begin{array}{l}2.60 \mathrm{~b} \\
(6.38)\end{array}$ & 60.63 & 80.09 & 92.22 & 89.32 \\
\hline P4 & $\begin{array}{l}0.99 \mathrm{ab} \\
(0.50)\end{array}$ & $\begin{array}{l}3.21 \mathrm{bc} \\
(10.08)\end{array}$ & $\begin{array}{l}1.48 \mathrm{ab} \\
(1.88)\end{array}$ & $\begin{array}{l}3.40 \mathrm{bc} \\
(11.90)\end{array}$ & 27.50 & 60.69 & 94.49 & 80.10 \\
\hline P5 & $\begin{array}{l}1.01 \mathrm{~b} \\
(0.53)\end{array}$ & $\begin{array}{l}4.05 \mathrm{c} \\
(17.45)\end{array}$ & $\begin{array}{l}2.48 c \\
(5.75)\end{array}$ & $\begin{array}{l}4.11 \mathrm{c} \\
(16.68)\end{array}$ & 23.13 & 41.09 & 84.84 & 73.72 \\
\hline LSD 5\% & 0.12 & 1.01 & 0.79 & 1.03 & & & & \\
\hline $\mathbf{C V}$ & 8.04 & 21.61 & 20.95 & 17.95 & & & & \\
\hline
\end{tabular}

Table 1: Average Total Dry Weight of Weed with Various Weed Control Treatments.

Note: Numbers followed by the same letters for the same columns show no significant difference based on the LSD ( Least

Significant Difference) $5 \%$ test. $C V=$ Coefficient of variance. DAP = days after planting. Numbers in parentheses are original numbers. Transformation $\sqrt{ }(x+0.5)$. 
The dry weight of weed in the P2 (weeding at 15 DAP, 30 DAP and 45 DAP), P3 (herbicide application + weeding at 30 DAP), P4 (silver black plastic mulch + weeding at 30 DAP) and P5 (rice straw mulch + weeding at 30 DAP) treatments were significantly lower compare to without weed control. The WCE of weeds were significantly higher at P1 (weed-free) treatment being 61.25, 98.55, 98.92 and $97.88 \%$ as observed at 15-60 dap. A research by Kumar with onion (2014) showed that the population and dry weight of weeds are significantly higher if weeds are not controlled and are lower when weed are controlled. Priya, et al. (2017) stated that oxyfluorfen herbicide is widely used by farmers at low doses and is easy to use, both pre and post-emergence and to control annual and perennial broadleaf weeds in a various field crops.

\subsection{Component of Growth}

Plant length did not differ between weed control treatments at 15 and 60 DAP observations and was significantly different at 30 and 45 DAP observations (Table 2).

Table 2: Average Plant Length of Shallot with Various Weed Control Treatments.

\begin{tabular}{ccccc}
\hline \multirow{2}{*}{ Treatments } & \multicolumn{4}{c}{ Observed plant length (cm) at various DAP } \\
\cline { 2 - 5 } & $\mathbf{1 5}$ & $\mathbf{3 0}$ & $\mathbf{4 5}$ & $\mathbf{6 0}$ \\
\hline P0 & 20.78 & $43.90 \mathrm{~b}$ & $49.79 \mathrm{~b}$ & 23.88 \\
P1 & 20.58 & $37.85 \mathrm{a}$ & $43.46 \mathrm{a}$ & 29.33 \\
P2 & 21.50 & $38.50 \mathrm{a}$ & $40.08 \mathrm{a}$ & 21.50 \\
P3 & 21.64 & $36.85 \mathrm{a}$ & $41.90 \mathrm{a}$ & 27.12 \\
P4 & 21.96 & $43.83 \mathrm{~b}$ & $42.67 \mathrm{a}$ & 26.71 \\
P5 & 21.10 & $42.10 \mathrm{ab}$ & $40.52 \mathrm{a}$ & 27.90 \\
\hline LSD 5\% & $\mathrm{NS}$ & 5.29 & 3.22 & $\mathrm{NS}$ \\
\hline CV & 5.90 & 8.67 & 8.48 & 25.07
\end{tabular}

Notes: Numbers followed by the same letters for the same columns show no significant difference based on the LSD (Least

Significant Difference) $5 \%$ test. $C V=$ Coefficient of variance. DAP = Days after planting. NS = Non significant.

Table 3: Average Number of Leaves of Shallot with Various Weed Controls Treatments.

\begin{tabular}{ccccc}
\hline \multirow{2}{*}{ Treatments } & \multicolumn{4}{c}{ Number of Leaves (leaves / plants) at Observation (DAP) } \\
\cline { 2 - 5 } & $\mathbf{1 5}$ & $\mathbf{3 0}$ & $\mathbf{4 5}$ & \multicolumn{1}{c}{$\mathbf{6 0}$} \\
\hline P0 & 11.98 & $13.83 \mathrm{a}$ & $14.08 \mathrm{a}$ & $3.96 \mathrm{a}$ \\
P1 & 14.20 & $17.95 \mathrm{c}$ & $30.79 \mathrm{~d}$ & $9.46 \mathrm{c}$ \\
P2 & 12.40 & $14.30 \mathrm{ab}$ & $22.54 \mathrm{bc}$ & $6.10 \mathrm{ab}$ \\
P3 & 13.00 & $14.95 \mathrm{ab}$ & $23.92 \mathrm{c}$ & $7.42 \mathrm{~b}$ \\
P4 & 12.95 & $14.79 \mathrm{ab}$ & $20.54 \mathrm{~b}$ & $5.33 \mathrm{ab}$ \\
P5 & 12.30 & $15.30 \mathrm{~b}$ & $21.29 \mathrm{bc}$ & $5.60 \mathrm{ab}$ \\
\hline LSD 5\% & $\mathrm{ns}$ & 1.66 & 3.22 & 3.26 \\
\hline CV & 8.22 & 7.24 & 9.63 & 34.25
\end{tabular}

Notes: Numbers followed by the same letters for the same columns show no significant difference based on the LSD (Least Significant Difference) $5 \%$ test. CV= Coefficient of variance. DAP = days after planting. NS = non significant.

Table 4. Average Number of Tillers of Shallots In Various Weed Control Treatments.

\begin{tabular}{ccccc}
\hline \multirow{2}{*}{ Treatments } & \multicolumn{4}{c}{ Observed number of tillers (tillers/ plants) at various DAP } \\
\cline { 2 - 5 } & $\mathbf{1 5}$ & $\mathbf{3 0}$ & $\mathbf{4 5}$ & $\mathbf{6 0}$ \\
\hline P0 & 3.21 & 3.83 & 4.25 & $3.33 \mathrm{a}$ \\
P1 & 3.79 & 4.75 & 5.04 & $4.83 \mathrm{~b}$ \\
P2 & 3.58 & 4.20 & 4.25 & $4.80 \mathrm{~b}$ \\
P3 & 3.46 & 4.12 & 4.25 & $4.75 \mathrm{~b}$ \\
P4 & 3.67 & 4.13 & 4.25 & $4.00 \mathrm{~b}$ \\
P5 & 3.41 & 4.20 & 4.46 & $5.00 \mathrm{~b}$ \\
\hline LSD 5\% & NS & NS & NS & 0.87 \\
\hline CV & 10.62 & 8.27 & 10.52 & 12.95 \\
\hline
\end{tabular}

Notes: Numbers followed by the same letters for the same columns show no significant difference based on the LSD (Least

Significant Difference) $5 \%$ test. CV = Coefficient of variance. DAP = Days after planting. NS = Non significant. 
Table 5: Average Fresh Weight of Shallot Bulbs In Various Weed Control Treatments.

\begin{tabular}{ccccc}
\hline \multirow{2}{*}{ Treatments } & \multicolumn{4}{c}{ Observed fresh weight of bulbs (g/ plant) at various DAP } \\
\cline { 2 - 5 } & $\mathbf{1 5}$ & $\mathbf{3 0}$ & $\mathbf{4 5}$ & $\mathbf{6 0}$ \\
\hline P0 & 1.06 & $3.46 \mathrm{a}$ & $6.96 \mathrm{a}$ & $11.46 \mathrm{a}$ \\
P1 & 1.48 & $5.67 \mathrm{bc}$ & $23.13 \mathrm{~d}$ & $41.21 \mathrm{c}$ \\
P2 & 1.30 & $5.60 \mathrm{bc}$ & $17.88 \mathrm{bc}$ & $33.58 \mathrm{~b}$ \\
P3 & 1.26 & $5.21 \mathrm{~b}$ & $19.85 \mathrm{~cd}$ & $34.17 \mathrm{~b}$ \\
P4 & 1.35 & $6.38 \mathrm{c}$ & $15.38 \mathrm{bc}$ & $33.75 \mathrm{~b}$ \\
P5 & 1.40 & $5.10 \mathrm{~b}$ & $13.63 \mathrm{~b}$ & $32.13 \mathrm{~b}$ \\
\hline LSD 5\% & NS & 1.02 & 5.44 & 4.56 \\
\hline CV & 14.76 & 12.92 & 22.38 & 9.76
\end{tabular}

Notes: Numbers followed by the same letters for the same columns show no significant difference based on the LSD ( Least Significant Difference) $5 \%$ test. $C V=$ Coefficient of variance. $D A P=$ Days after planting. $N S=$ Non significant .

Tabel 6: Average Dry Weight of Shallot Bulbs In Various Weed Control Treatments..

\begin{tabular}{ccccc}
\hline \multirow{2}{*}{ Treatment } & \multicolumn{4}{c}{ Observed dry weight of bulbs (g/ plant) at various DAP } \\
\cline { 2 - 5 } & $\mathbf{1 5}$ & $\mathbf{3 0}$ & $\mathbf{4 5}$ & $\mathbf{6 0}$ \\
\hline P0 & 0.38 & $0.98 \mathrm{a}$ & $4.40 \mathrm{a}$ & $7.96 \mathrm{a}$ \\
P1 & 0.45 & $1.41 \mathrm{~b}$ & $15.71 \mathrm{c}$ & $32.12 \mathrm{c}$ \\
P2 & 0.42 & $1.00 \mathrm{a}$ & $12.83 \mathrm{bc}$ & $26.30 \mathrm{~b}$ \\
P3 & 0.41 & $1.05 \mathrm{a}$ & $13.67 \mathrm{bc}$ & $26.08 \mathrm{~b}$ \\
P4 & 0.44 & $0.95 \mathrm{a}$ & $11.63 \mathrm{bc}$ & $26.58 \mathrm{~b}$ \\
P5 & 0.43 & $0.90 \mathrm{a}$ & $10.00 \mathrm{~b}$ & $25.30 \mathrm{~b}$ \\
\hline LSD 5\% & NS & 0.27 & 4.37 & 11.66 \\
\hline CV & 24.48 & 17.10 & 25.50 & 4.25
\end{tabular}

Notes: Numbers followed by the same letters for the same columns show no significant difference based on the LSD ( Least

Significant Difference) $5 \%$ test. $C V=$ Coefficient of variance. DAP = Days after planting. NS = Non significant.

At 30 DAP and 45 DAP, the length of plants with the P0 treatment (without weed control) was $43.90 \mathrm{~cm}$ and 49.79 $\mathrm{cm}$, significantly longer than with the other treatments. Plant length with the the P1 treatment (weed free) was of 37.85 and $43.46 \mathrm{~cm}$ and not significantly different from the P2 (weeding at 15, 30 and 45 DAP), P3 (herbicide application + weeding at $30 \mathrm{DAP}), \mathrm{P} 4$ (silver black plastic mulch + weeding at 30 DAP) and P5 (rice straw mulch + weeding at 30 DAP treatments. For the number of leaves, there was no difference among treatments of weed control as observed at $15 \mathrm{DAP}$ and there were significant differences as observed at 30, 45 and 60 DAP (Table 3). Observation made at 30,45 and 60 DAP showed that the number of leaves with the P1 (weed-free) treatment (17.95, $30.79,9.46 /$ plant) was significantly higher than that of the other treatments. The number of leaves was significantly lower in the P0 treatment (without weed control) being 13.83, 14.08, 3.96/ plant. The number of leaves with P2 (weeding at 15, 30 and 45 DAP), P3 (herbicide application + weeding at 30 DAP, P4 (silver black plastic mulch + weeding at 30 DAP and P5 (rice straw mulch + weeding at 30 DAP) treatments were generally no different. Murthy, et al. (2009) reported that the number of leaves was significantly higher in weed-free treatment up to 60 days after planting.

In the number of tillers there was no difference between weed control treatments at observations of 15 DAP to 45 DAP (Table 4). At 60 days after planting, the number of tillers in weed-free treatment (4.83 tillers/ plant) did not differ from other weed control treatments (4.00 - 5.00 tillers/ plant). The number of tillers was significantly lower in the treatment without weed control (P0) being 3.33 tillers/ plant.

For the fresh weight of the bulbs there was no difference among weed control treatments as observed at 15 DAP (Table 5). At 30 DAP, the fresh weight of bulbs with the P1 (weed-free) treatment was $5.67 \mathrm{~g} /$ plant and was not different from P4 (silver black plastic mulch + weeding at 30 DAP) treatment, being $6.38 \mathrm{~g} /$ plant and P2 (weeding at $15 \mathrm{DAP}, 30 \mathrm{DAP}$ and $45 \mathrm{DAP}$ ) treatment, being $5.60 \mathrm{~g} /$ plant. At 45 DAP, the fresh weight of bulbs with the P1 (weed-free) treatment was $23.13 \mathrm{~g} /$ plant and was not significantly different from P3 (herbicide + weeding application at 30 DAP) treatment, which of $19.85 \mathrm{~g} /$ plant. The fresh weights of bulbs with other weed control treatments were lower. Furthermore, at 60 days after planting, the fresh weight of bulbs was significantly 
heavier at P1 (weed free) treatment, being $41.21 \mathrm{~g} /$ plant. The fresh weight of bulbs was significantly heavier with P2 (weeding at 15 DAP, 30 DAP and 45 DAP), P3 (herbicide application + weeding at 30 DAP), P4 (silver black plastic mulch + weeding at $30 \mathrm{DAP}$ ) and P5 (rice straw mulch + weeding at 30 DAP) compared to P0 treatment (without weed control). The fresh weight of bulbs was significantly lower with the P0 treatment (without weed control) as observed at 15 DAP up to 60 DAP, weighing 1.06, 3.46, 6.96 and $11.46 \mathrm{~g} / \mathrm{plant}$ respectively.

The dry weights of bulbs/ plant among weed control treatments did not differ as observed at 15 DAP (Table 6). At observed at ages 30, 45 and 60 DAP, the dry weight of bulbs/ plant was significantly heavier with the P1 (weedfree) treatment, being $1.41,15.71$ and $32.12 \mathrm{~g} /$ plant. The significantly lowest dry weight of bulbs was with P0 (without weed control) treatment, being of 0.98, 4.40 and $7.96 \mathrm{~g} /$ plant. Meanwhile, the dry weight of bulbs with the P2 (weeding at 15 DAP, 30 DAP and 45 DAP), P3 (herbicide application + weeding at $30 \mathrm{DAP}$ ), P4 (silver black plastic mulch + weeding at $30 \mathrm{DAP}$ ) and P5 (rice straw mulch + weeding at 30 DAP) 30 DAP) treatments was significantly higher than with P0 (without weed control) treatment.

\subsection{Yield Component}

Table 7: Average Yield Components of Shallots on Various Weed Control Treatments.

\begin{tabular}{ccccccc}
\hline & \multicolumn{5}{c}{ Average } \\
\cline { 2 - 7 } Treatments & $\begin{array}{c}\text { Number of } \\
\text { Bulbs (bulbs } \\
\text { / plants) }\end{array}$ & $\begin{array}{c}\text { Bulbs Fresh } \\
\text { Weight of } \\
\text { (g/ plant) }\end{array}$ & $\begin{array}{c}\text { Bulbs Dry } \\
\text { Weight }(\mathbf{g} / \\
\text { lant) }\end{array}$ & $\begin{array}{c}\text { Bulbs Dry } \\
\text { Weight (g/ } \\
\text { harvest } \\
\text { plot) }\end{array}$ & $\begin{array}{c}\text { Yield } \\
\text { (t/ha) }\end{array}$ & $\begin{array}{c}\text { Weed } \\
\text { Index }\end{array}$ \\
\hline P0 & 5.25 & $13.96 \mathrm{a}$ & $10.63 \mathrm{a}$ & $173.50 \mathrm{a}$ & $3.05 \mathrm{a}$ & 74.77 \\
P1 & 5.58 & $47.96 \mathrm{c}$ & $39.21 \mathrm{c}$ & $687.75 \mathrm{c}$ & $12.08 \mathrm{c}$ & - \\
P2 & 5.20 & $40.40 \mathrm{~b}$ & $33.50 \mathrm{~b}$ & $597.50 \mathrm{~b}$ & $10.50 \mathrm{~b}$ & 13.12 \\
P3 & 5.25 & $39.83 \mathrm{~b}$ & $33.17 \mathrm{~b}$ & $561.25 \mathrm{~b}$ & $9.86 \mathrm{~b}$ & 18.39 \\
P4 & 5.71 & $40.21 \mathrm{~b}$ & $33.58 \mathrm{~b}$ & $564.00 \mathrm{~b}$ & $9.91 \mathrm{~b}$ & 17.99 \\
P5 & 5.20 & $36.80 \mathrm{~b}$ & $29.90 \mathrm{~b}$ & $556.30 \mathrm{~b}$ & $9.77 \mathrm{~b}$ & 19.12 \\
\hline LSD 5\% & $\mathrm{ns}$ & 5.45 & 4.97 & 74.22 & 0.62 & \\
\hline CV & 9.55 & 9.91 & 11.00 & 9.42 & 9.42 &
\end{tabular}

Notes: Numbers followed by the same letters for the same columns show no significant difference based on the LSD ( Least Significant Difference) $5 \%$ test. CV= Coefficient of variance. DAP = Days after planting. NS = Non significant

\section{CONCLUSION}

Weed control has a significant effect in controlling weeds and increasing the growth and yield of shallots. With the weed-free treatment, weed dry weight was significantly
Weed control treatment significantly affected the fresh weight of bulbs/ plants, dry weight of bulbs/ plants, dry weight of bulbs/ harvest plot $(0.47 \mathrm{~m} 2)$ and crop yields/ ha (Table 7). The number of bulbs/ plant did not show a difference among weed control treatments. For the P1 (weed-free) treatment, the fresh weight of bulbs per plant (47.96 g/ plant), dry weight of bulbs/ plant (39.21 g/ plant), dry weight of bulbs/harvest plot $\left(687.75 \mathrm{~g} / 0.47 \mathrm{~m}^{2}\right)$ and yield/ha (12.08 t/ ha) were significantly higher than other weed control treatments, and significantly lowest for P0 (without weed control) treatment, being $3.05 \mathrm{t} / \mathrm{ha}$. The yield component for P2 (weeding at 15 DAP, 30 DAP and 45 DAP), P3 (herbicide application + weeding at 30 DAP), P4 (silver black plastic mulch + weeding at 30 DAP) and P5 (rice straw mulch + weeding at 30 DAP) treatments showed no difference and were significantly higher compared to P0 (without weed control) treatment. Weed index was significantly lower for the P2, P3, P4 and P5 treatment, being 13.12, 18.39, 17.99 and 19.12 compared to P0 of 74.77. Uygur, et al. (2010) stated that the highest onion yield was for weed-free treatment, followed by oxadiazon herbicide and oxyfluorfen herbicide. Poddar, et al. (2017), stated that the application of oxyfluorfen herbicide at a dose of $200 \mathrm{~g} / \mathrm{ha}+$ weeding at 30 days significantly decreased the weed density and dry weight and increased the bulb yield of onion. Qosem (2015) reports that onion yields decrease by $87 \%$ if weeds are not controlled during the growth period of the plant. 
mulch + weeding at 30 DAP) treatments had significant effects in controlling weed growth as well as increasing the growth and yield of shallots compared to without weed control.

\section{ACKNOWLEDGEMENTS}

This research was funded by Research Grant for Professor from the Rector of Brawijaya University and Agricultutre Faculty, Brawijaya University (PNBP.DIPA042.01.2.400919/2019).

\section{REFERENCES}

[1] Center for Data and Agriculture and Information System. 2016. Outlook of Onion. Center for Data and Agriculture and Information System, Ministry of Agriculture. http://epubliksi.setjen.pertanian.go.id/file/301--outlookbawang merah-2016.

[2] Bhullar,M.S., Kaur,T., Kaur, S. and Yadav, R. 2015. Weed management in vegetable and flower crop-based system. Indian Journal of Weed Science 47(3): 277-287. http://isws.org.in/IJWSn/File/2015_47_Issue-3_277287.pdf.

[3] Kumar, U. 2014. Weed management studies in onion (Allium cepa L.). The Asian Journal of Horticultura 9(2): 426-430. DOI:10.15740/HAS/TAJH/9.2/426-430.

[4] Murthy, K. N.K., Fathima,P.S. and Vidya, A. 2009. Effect of crop weed competition on the performance of direct seeded onion (Allium cepa L.). International Journal of Agricultural Science 5(2): 558- 583 https://pdfs.semanticscholar.org/7bf4/d3aa4eb05d466bc75d c0724dc95d28013e74.pdf.

[5] Poddar, R., Bera, S. and Ghost, R.K. 2017. Weed management in onion through oxyfluorfen and its effect on soil microflora and succeeding crop of balckgram. Indian Journal of weed science 49(1): 47-50. DOI:10.5958/09748164.2017.00012.0

[6] Prachand,S., Kubde, K.J. and Bankar,S. 2014. Effect of chemical weed control on weed parameters,growth, yield attributes,yield and economics in soybean (Glycine max). American Eurasian J.Agric.\& Environ.Sci. 14(8): 698-701. DOI: 10.5829/idosi.aejaes.2014.14.08.12376.

[7] Priya,R.S., Chinnusamy,C., Janaki,P. and Arthanari.P.M. 2017. Persistence and carryover effect of oxyfluorfen residues in red sandy clay loam soil. Journal of Pharmacognosy and Phytochemistry 6(3): 527-532. http://www.phytojournal.com/archives/2017/vol6issue3/Part I/6-3-108-760.pdf.

[8] Qasem,J.R. 2005. Critical period of weed competition in onion (Alium cepa L.) in Jordan. Jordan Journal of Agriculture Science 1(1). https://journals.ju.edu.jo/JJAS/article/view/1286/5935.

[9] Sekara, A., Pokluda, R.,Vacchio,L.D., Somma, S., Caruso, G. 2017. Interaction among genotype,environment and agronomic practices on production and quality of storage onion (Allium cepa L.) - A review. Hort.Sci. (Prague) 44(1): 21-42. DOI:10.17221/92/2015-HORTSCI.
[10] Tripathy, P., Sahoo,B.B., Patel, D and Dash, D.K. 2013. Weed management studies in onion (Allium cepa L.). Journal of Crop and Weed 9(2): 210-212. DOI:10.13140/RG.2.2.27442.71360.

[11] Uygur, S., Gürbüz, R. and Uygur, F.N. 2010. Weed of onion fields and effects on some herbicides on weeds in Cukurova region, Turkey. African Journal of Biotechnology 9(42): 7037-7042. DOI.10.5897/AJB10.1005.

[12] Vijayvergiya, D., Ali, S.A., Das, M.P., Ramgiry, P. and Uikey,S. 2018. Effect of pre-emergence herbicides on weed control of kharif onion (Allium cepa L.) in vindhyan plateu of Madhya Pradesh. The Pharma Innovation Journal 7(1): 376-378.

http://www.thepharmajournal.com/archives/2018/vol7issue1 /PartF/7-1-42-359.pdf. 